\title{
Effects of Adrenal Medulla Grafts on Plasma Catecholamines and Rotational Behavior
}

\author{
Hidetoshi Takashima, Maciej Poltorak, Jill B. Becker, ${ }^{*}$ and William J. Freed \\ Preclinical Neurosciences Section, Neuropsychiatry Branch, NIMH Neuroscience Center at St. Elizabeth's, Washington, D.C. 20032; and \\ *Department of Psychology and Neuroscience Program, University of Michigan, Ann Arbor, Michigan 48104
}

The mechanisms by which adrenal medulla grafts infuence the function of host brains in animal models of Parkinson's disease are unclear. To explore this issue, fragments of adrenal medulla or sciatic nerve were transplanted into the lateral ventricle of bilaterally adrenalectomized (ADX) or sham-ADX rats with unilateral 6-hydroxydopamine lesions of the substantia nigra. Additional control group received sham-transplantation surgery. Behavioral effects of these procedures were tested following administration of apomorphine, amphetamine, or nicotine. Plasma catecholamines were measured before and after transplantation surgery. In both ADX and sham-ADX rats, adrenal medulla grafts produced greater decreases in apomorphine-induced rotational behavior than did sciatic nerve grafts or sham-transplanted groups. Decreases in rotation were smaller in ADX than in sham-ADX animals, regardless of graft treatment. Plasma catecholamines increased after transplantation surgery in each of the sham-ADX groups, regardless of graft type. Increases in plasma dopamine concentrations were associated with decreases in rotational behavior. Five months after transplantation, grafted chromaffin cells demonstrated catecholamine fluorescence, tyrosine hydroxylase (TH) and chromogranin $A$ immunoreactivities, and expression of TH mRNA. It is concluded that adrenal medulla grafts produce decreases in apomorphine-induced rotation through a combination of two independent effects. One is a specific effect of adrenal medulla grafts. The second is a nonspecific effect that requires an intact adrenal gland and may be related to increases in plasma catecholamine concentrations. (c) 1992 Academic Press, Inc.

\section{INTRODUCTION}

Loss of dopaminergic terminals in the striatum resulting from the degeneration of substantia nigra dopamine neurons is responsible for a majority of the symptoms in Parkinson's disease (22). Animal models of this disorder have been developed, using the neurotoxins 6 hydroxydopamine (6-OHDA) or $N$-methyl-4-phenyl- 1,2,3,6-tetrahydropyridine (MPTP), to destroy the substantia nigra dopamine neurons $(10,25,45,46)$. In attempts to compensate for this deficit, cells and tissue fragments including fetal substantia nigra and adrenal medulla have been employed for transplantation in rats, monkeys, and even in human patients $(2,8,11,16,21$, $27,29,31,33,36,42$, for reviews cf. 19, 20). In clinical applications, adrenal medulla autografts have been employed as a source of catecholamine secreting cells in order to avoid the immunological, practical, and ethical constraints related to the use of fetal nigral tissue.

In the 6-OHDA-lesion animal model of Parkinson's disease, adrenal medulla grafts implanted into the lateral ventricle or caudate-putamen have been found to reduce some of the behavioral manifestations of nigrostriatal dopamine depletion $(4,16,40,41)$. However, the mechanism by which these grafts influence the functioning of the host brain is still unclear. Initially, it was suggested that this functional effect was produced through secretion of catecholamines into the extracellular space, via a paracrine-like mechanism, because adrenal chromaffin cells do not innervate the host neostriatum when transplanted into the lateral ventricle of unilaterally lesioned rats $(17,18)$. This idea has not, however, been supported by any direct evidence. Dopamine in CSF has not been shown to increase in animal studies $(4,5)$ or in most clinical studies $(44)$.

A second possible explanation for the behavioral effects of adrenal medulla grafts involves trophic effects on surviving components of host dopaminergic systems. Enhanced tyrosine hydroxylase (TH) immunoreactivity has been observed in areas adjacent to adrenal medulla grafts $(3,9,15)$ or following administration of bFGF into the striatum (32). Nonchromaffin tissue, such as sciatic nerve tissue, has been reported to reduce behavioral deficits when combined with chronic infusions of nerve growth factor (34), which may also be a manifestation of some form of trophic effect. Whether such trophic effects account for the behavioral effects of adrenal medulla grafts in animals with nigrostriatal dopamine depletion is still unclear. A related possibility is that adrenal medulla grafts could supply the host brain with 
specific cell adhesion molecules or their fragments as well as extracellular matrix components present in adrenal medulla, which in turn could contribute to the functional effects of the grafts (35).

We have also hypothesized that dopamine may be secreted from adrenal medulla grafts into local blood vessels, thereby gaining access to the striatum via the compromised blood-brain barrier $(4,6,7)$. In support of this hypothesis, we found a correlation between decreases in apomorphine-induced rotational behavior and increases in concentrations of dopamine in the blood (4, 6). A similar correlation was not found in adrenalectomized (ADX) rats, suggesting a possible role of the host adrenal gland in mediating the changes in blood dopamine concentrations (7). These previous experiments did not, however, include control groups without adrenal medulla grafts. Because the relative roles of adrenal medulla grafts and host adrenal glands in producing changes in blood catecholamines and rotational behavior could not be determined, the present experiment was undertaken. We wished to determine the specificity of adrenal medulla, as compared to sciatic nerve grafts or sham procedures, in effecting changes in apomorphineinduced rotation and plasma catecholamines in both ADX animals and in animals with intact adrenal grands (sham ADX).

\section{MATERIALS AND METHODS}

\section{Animals and Surgery}

Studies were carried out on male rats of the SpragueDawley strain (Zivic-Miller Laboratories) weighing $150-200 \mathrm{~g}$ at the beginning of the experiment. The animals received a bilateral adrenalectomy (ADX) or a sham operation including skin incision only (sham$\mathrm{ADX}$ ), performed by Zivic-Miller prior to delivery. They were housed with food and water (sham-ADX) or $1 \%$ saline (ADX) given ad libitum in an animal room with a $12 \mathrm{~h}$ light $/ 12 \mathrm{~h}$ dark cycle and controlled temperature. Animals were maintained according to the "NIH Guide for the Care and Use of Laboratory Animals."

Animals were anesthetized with ketamine and xylazine and placed in a stereotaxic apparatus with the skull horizontal. Animals received a unilateral 6-hydroxydopamine $\mathrm{HBr}$ (Sigma Chemical Co.) infusion (8 $\mu \mathrm{g}$ free base in $4 \mu \mathrm{l}$ saline containing $0.05 \%$ ascorbic acid) into the substantia nigra (coordinates: $5 \mathrm{~mm}$ posterior and 2 $\mathrm{mm}$ lateral to bregma, $7.2 \mathrm{~mm}$ below the dura). The effectiveness of the lesion was examined by measuring complete $360^{\circ}$ rotations after $0.1 \mathrm{mg} / \mathrm{kg}$ apomorphine $\mathrm{HCl}(\mathrm{SC})(47)$ in cylindrical jars with flat bottoms using automated rotometer devices (17). Only animals displaying more than 100 turns/h contralateral to the lesion after apomorphine injection were used for further experiments.

\section{Behavioral Testing, Plasma Catecholamines, and Grafting Procedures}

Starting 3 weeks after lesioning animals were tested for rotational behavior following $0.05 \mathrm{mg} / \mathrm{kg}$ apomorphine (SC) (four tests) and $0.75 \mathrm{mg} / \mathrm{kg}$ amphetamine (ip) (one test). The number of clockwise and counterclockwise turns was recorded separately for each animal at 5-min intervals for $75 \mathrm{~min}$. Plasma samples were collected from the intraorbital sinus under ether anesthesia and assayed for catecholamines using high-performance liquid chromatography with electrochemical detection (4).

Animals received intraventricular adrenal medulla grafts $(n=50)$, sciatic nerve grafts $(n=31)$, or a sham procedure $(n=19)$ on the lesioned side. (Coordinates for the graft: $1.5 \mathrm{~mm}$ lateral, $1.5 \mathrm{~mm}$ anterior to the bregma, and $3.5 \mathrm{~mm}$ below the dura, bite-bar set at 5.0 $\mathrm{mm}$ above the interaural line.) The sham procedure consisted of making a burr-hole in the skull. Adrenal glands for grafts were harvested from 5-week-old (100$120 \mathrm{~g})$ male Sprague-Dawley rats. The adrenal medullae were dissected free of the cortex and transplanted as previously described (17). Sciatic nerve was obtained at the same time from the same donor animals.

Postgraft testing began 4 weeks after transplantation. The animals were tested for apomorphine (four tests), amphetamine (one test), and $1.1 \mathrm{mg} / \mathrm{kg}$ nicotine ditartrate (SC)-induced rotation (one test). Ten weeks after the graft, plasma samples were collected and assayed for catecholamines a second time. Animals that were not used for histology were also retested 9 months after transplantation with $0.05 \mathrm{mg} / \mathrm{kg}$ apomorphine for four sessions.

\section{Histology}

Brains were studied 5 and 10 months after transplantation. Brains were processed for glyoxylic acid-induced fluorescence as described by De la Torre (43), with magnesium perfusion (28). Immunolabeling of TH (monoclonal anti-TH Ab, Boehringer-Mannheim Biologicals, 1:200 dilution, and polyclonal anti-TH Ab, Eugene Tech International, Inc., 1:500 dilution) and chromogranin type A (Boehringer-Mannheim Biologicals, 1:25 dilution) was performed according to Schachner (39) with minor modifications. In situ hybridization histochemistry was performed using an alkaline phosphatase-labeled oligonucleotide TH mRNA probe (NEN Research Products, Du Pont Company) according to the manual provided with the probe. For hybridization normal adrenal medulla tissue was used as a positive control and a sham-grafted brain was used as a negative control.

\section{Statistics}

Apomorphine-induced rotation was tested four times before and after transplantation. These data were con- 
verted to percentage reductions of mean number of rotations as compared to baseline (pretransplantation) data. For analysis of variance, the SuperANOVA program (Abacus Concepts, Inc., Berkeley, CA) was used, with post hoc testing by the Bonferroni/Dunn procedure. Details of individual statistical tests are given in the figure legends. Other statistical calculations were performed with the aid of the Stat View $512+$ program (BrainPower, Inc., Calabasas, CA).

\section{RESULTS}

\section{Rotational Behavior}

Apomorphine-induced postgraft rotation was expressed as the percentage change from baseline using the mean number of rotations for each individual animal. In the adrenal medulla grafted groups 35 out of 50 animals showed $>10 \%$ decrease in rotation. Of these, 12 out of $24 \mathrm{ADX}$ and 23 out of 26 sham-ADX rats showed a $>10 \%$ decrease. In the sciatic nerve grafted groups 13 out of 31 showed a $>10 \%$ decrease and in the shamgrafted groups 6 out of 19 animals showed $a>10 \%$ decrease. The decrease in apomorphine-induced rotation in animals that received adrenal medulla grafts was significantly greater than that produced by sciatic nerve grafts $(P=0.02)$ or by sham grafts $(P<0.01)$ (Fig. 1$)$. No significant difference was found between the sciatic nerve graft and sham-graft groups $(P=0.08)$ (Fig. 1). The interaction between adrenalectomy and graft effects was not significant $(P=0.85$; cf. Fig. 1 legend). In animals tested for apomorphine-induced rotational behavior 1 and 9 months after transplantation, there was no significant decrement in the effect after 9 months as compared to 1 month after transplantation (Fig. 2). There was a tendency for the ADX rats to show an greater decrease in rotation after 9 months, although there were only five rats remaining in this group.

Only animals that made $\geq 50$ rotations on the pregraft amphetamine test were used to assess the effects of grafting on amphetamine-induced rotational behavior. There were no statistically significant effects of either graft group or ADX, although the mean numbers of rotations in the sciatic nerve and sham-graft groups did tend to increase as compared to the adrenal medulla graft groups (Fig. 3).

The different pharmacological tests of asymmetry in the striatum produced different behavioral responses. First, there was no correlation between responses to amphetamine and apomorphine in individual animals (Fig. 4a). Second, following the injection of $1.1 \mathrm{mg} / \mathrm{kg}$ nicotine tartrate, some animals showed ipsilateral rotations, but no animals turned contralaterally. The numbers of amphetamine-induced and nicotine-induced ipsilateral rotations were significantly correlated (Spearman's

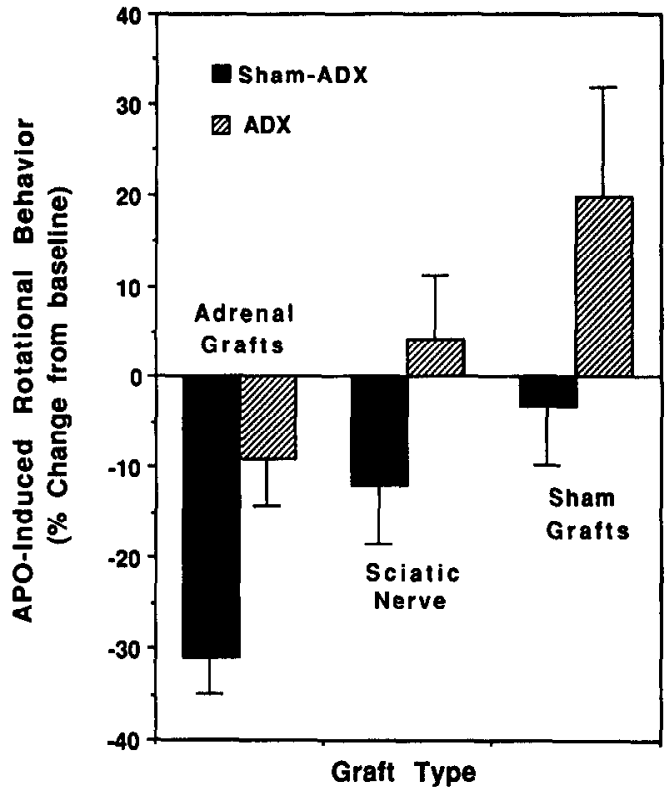

FIG. 1. Percentage change in the number of contralateral rotations induced by apomorphine (APO) $(0.05 \mathrm{mg} / \mathrm{kg} \mathrm{SC}$; means \pm SEM) for each group from 4 to 7 weeks after transplantation. A two-way analysis of variance for independent groups showed significant main effects of (i) adrenalectomy vs sham adrenalectomy (i.e., for all graft groups combined; $F(1,94)=14.168 ; P=0.0003$ ) and (ii) graft group $(F(2,94)=9.951 ; P=0.0001)$. The adrenalectomy $\mathrm{X}$ graft interaction was not significant $(F(2,94)=0.165 ; P=0.85)$. Multiple comparisons (Bonferroni/Dunn) revealed a significant difference between the adrenal medulla graft group $(n=50)$ and the sciatic nerve group $(n=31 ; P$ $=0.016)$ and also the sham group $(n=19 ; P=0.0001)$. The sciatic nerve and sham groups were not significantly different $(P=0.076)$.

rank correlation coefficient, $r_{\mathrm{s}}=0.47, P<0.01$, see Fig. 4b).

\section{Plasma Catecholamines}

In the sham-ADX groups, plasma catecholamines increased relative to catecholamine levels prior to transplantation $(P<0.01)$. Increases in plasma catecholamines were not seen in ADX animals regardless of the graft group (Fig. 5). There were no statistically significant differences between the different transplantation conditions (cf. Fig. 5 legend). In the sham-ADX/adrenal medulla grafted group, the increase in plasma dopamine concentrations (for the 17 out of 26 animals that showed increased plasma dopamine) was inversely correlated with the percentage of change in apomorphine-induced rotational behavior ( $r_{\mathrm{s}}=-0.60, P<0.01$, see Fig. 6). Similar correlations were not seen for norepinephrine or epinephrine. No correlation between plasma catecholamines and amphetamine-induced rotation was found.

\section{Histology}

Glyoxylic acid-induced catecholamine fluorescence and TH immunocytochemical staining revealed that the 


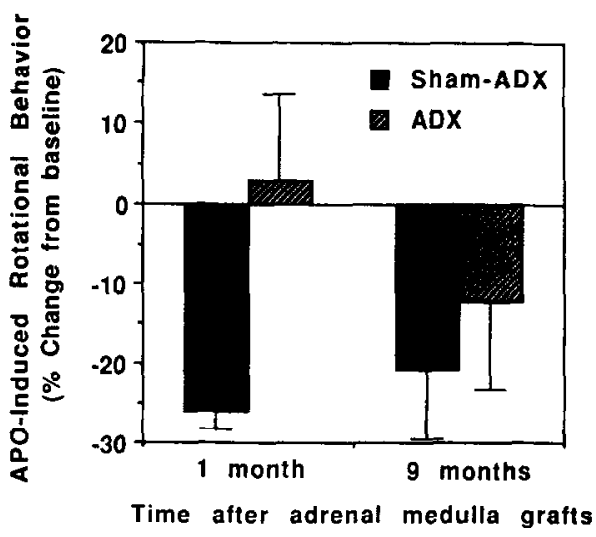

FIG. 2. Relative percentage change in apomorphine (APO)-induced rotational behavior in a subgroup of adrenal medulla grafted animals ( $n=11$ for sham-ADX and $n=5$ for ADX animals) that were tested both 1 and 9 months after transplantation. Many of the animals had been sacrificed prior to the ninth month for histology. Note that the decreases in rotation in the adrenal medulla grafted animals were maintained 9 months after transplantation.

substantia nigra lesions were complete and persistent. No residual $\mathrm{TH}$ immunoreactive fibers were seen in the striatum, and there were no TH positive fibers which appeared to be sprouting or regenerating.

Adrenal medulla grafts were examined histologically at $5(n=24)$ and 10 months $(n=9)$ after transplantation. At 5 months, grafts were found in 18 of the 24 animals examined (Fig. 7). In the other 6 animals, no graft or graft residue was found. For these animals a part of the brain rostral to the anterior commisure was

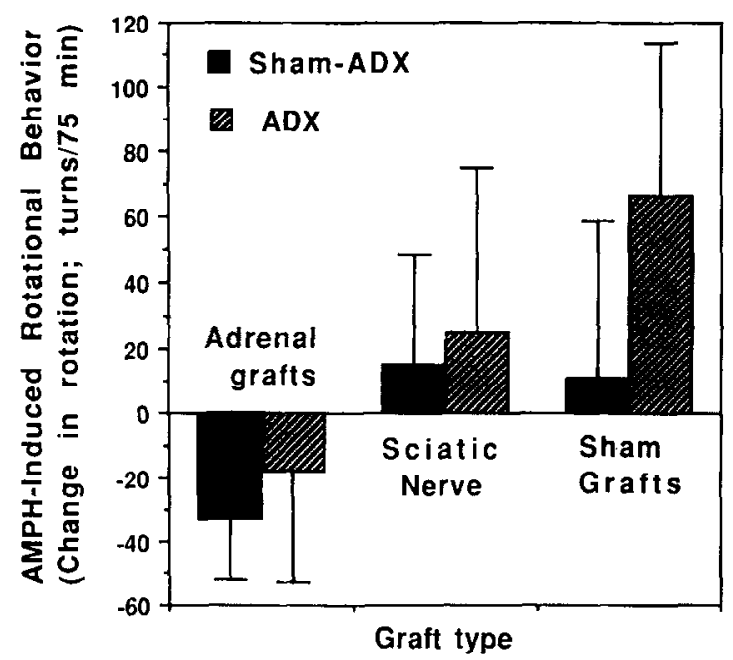

FIG. 3. Change in amphetamine (AMPH)-induced $(0.75 \mathrm{mg} / \mathrm{kg}$, ip) rotation produced by adrenal medulla grafts in animals that exhibited $\geq 50$ rotations $/ 75 \mathrm{~min}$ on the pregraft test. Bars represent the changes in ipsilateral rotations after transplantation (means \pm SEM). The effects of grafting on rotational behavior were not significant according to a two-way analysis of variance $(P=0.29)$. Note, however, that the pattern was similar to the changes in apomorphineinduced rotation.
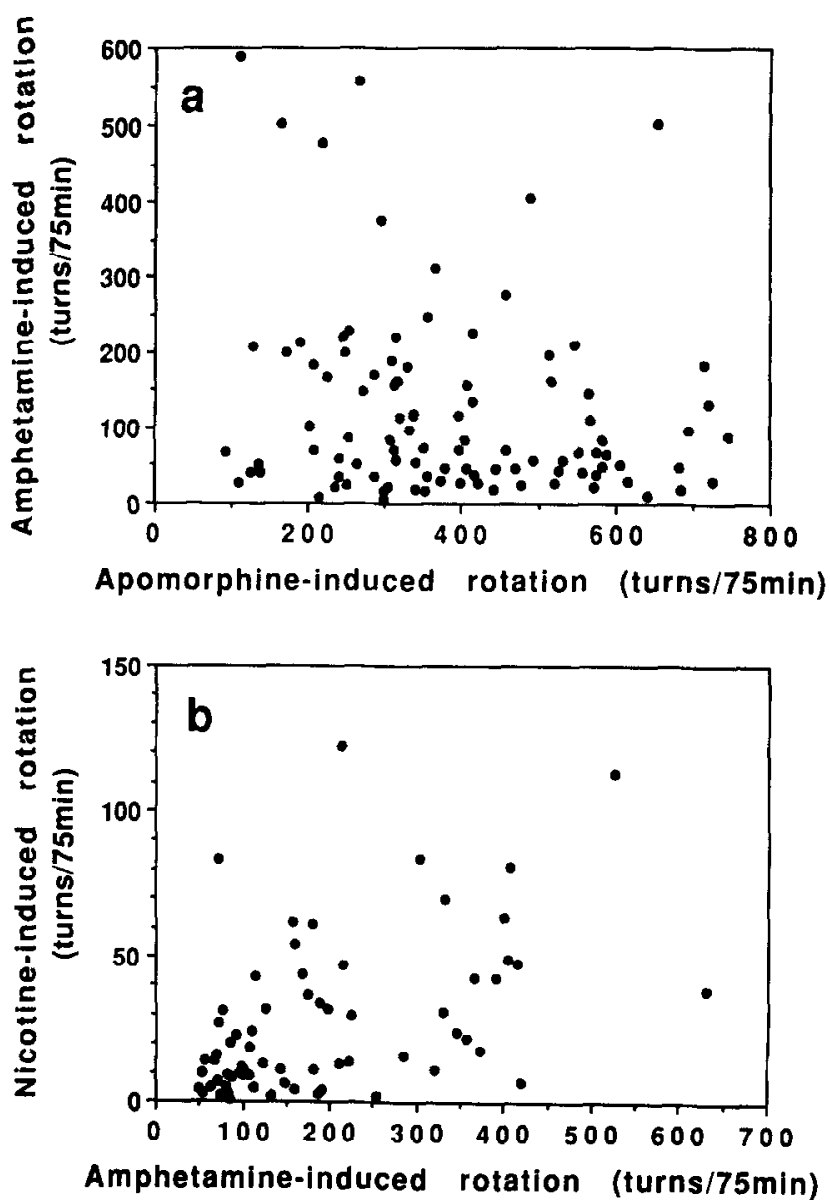

FIG. 4. (a) Scatter plot of amphetamine $(0.75 \mathrm{mg} / \mathrm{kg}$, ip)- versus apomorphine $(0.05 \mathrm{mg} / \mathrm{kg}, \mathrm{SC})$-induced rotational behavior in individual animals. No correlation was found between the two behaviors (Spearman's rank correlation coefficient, $r_{\mathrm{s}}=-0.188$ ). (b) Correlation between amphetamine $(0.75 \mathrm{mg} / \mathrm{kg}$, ip) and nicotine tartrate (1.1 $\mathrm{mg} / \mathrm{kg}, \mathrm{SC}$ )-induced rotational behavior. Some animals showed significant ipsilateral rotation following the injection of nicotine. No animals showed significant contralateral rotation. These data show a significant correlation between the two behaviors (Spearman's rank correlation coefficient, $r_{\mathrm{s}}=0.473, P<0.01$ ).

not saved. Thus it cannot be concluded with certainly that the grafts did not survive in these cases. Most grafts were small in size and found to be located in the rostral part of the lateral ventricle. The grafts were adherent to the ventricular ependyma and in contact with the host striatum. Surviving chromaffin cells were found in 16 of these grafts. In the other 2 animals, the grafts had degenerated and no chromaffin cells were found. The surviving chromaffin cells were positive for catecholamine fluorescence (Fig. 7A), chromogranin A immunoreactivity (Fig. 7B), TH immunoreactivity (Figs. 7C and 8), and TH mRNA (Fig. 9A). In general, surviving chromaffin cells did not develop extensive processes, and were either round or polygonal in shape. An exact appraisal of the total number of surviving grafts or surviving cells cannot be made, because not all 


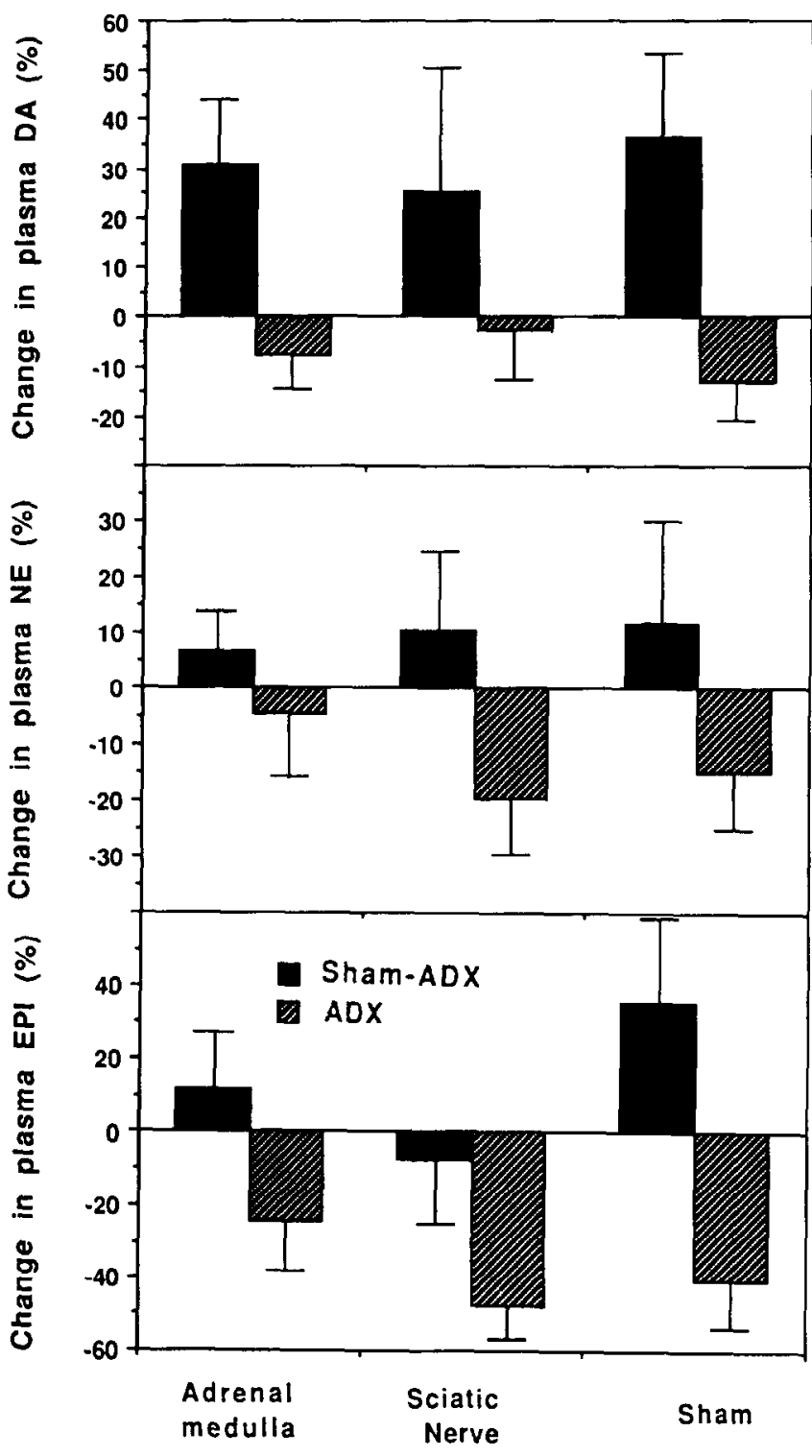

Graft type

FIG. 5. Percentage change in blood catecholamine concentrations after adrenal medulla grafts (mean \pm SEM). The figure demonstrates the changes in dopamine (DA), norepinephrine (NE), and epinephrine (EPI). After transplantation, catecholamines were increased in the sham-adrenalectomized (sham-ADX) animals as compared to the ADX groups $(P<0.01$ for dopamine and epinephrine, $P=0.03$ for norepinephrine for main effects by two-way analysis of variance). No statistically significant differences were observed between the graft groups for either the ADX or sham-ADX animals ( $P=0.99$ for dopamine, 0.88 for norepinephrine, and 0.31 for epinephrine by two-way analysis of variance).

sections from each graft were examined. There was, however, no obvious relationship between number of surviving chromaffin cells in individual animals and degree of behavioral effect. Sciatic nerve grafts also survived and were generally somewhat larger than the adrenal medulla grafts (Figs. 9 B-D).
Ten months after transplantation, graft tissue was found in 6 of the 9 animals examined (Fig. 8). Surviving chromaffin cells were found in four of these grafts, while in two grafts they had degenerated. The location and size of the grafts and the shape and appearance of surviving chromaffin cells were similar to those observed after 5 months. In general, there appeared to be a reduction in the number of surviving chromaffin cells and in background TH staining within the graft area. The cells appeared to be more isolated and less aggregated.

\section{DISCUSSION}

\section{Apomorphine-Induced Rotational Behavior}

In summary, adrenal medulla grafts were found to decrease apomorphine-induced rotation as compared to sciatic nerve or sham grafts. In addition, greater decreases in rotation were observed in animals with intact adrenal glands, as compared to ADX animals, regardless of transplantation procedure.

Adrenal medulla grafts have previously been found to produce decreases in apomorphine-induced rotational behavior as compared to sciatic nerve grafts $(16,34,41)$. The present study replicates this effect of adrenal chromaffin cells with a larger number of animals. Notwithstanding, the magnitude of the effect of adrenal medulla grafts was fairly small. Chromaffin cells in adrenal medulla grafts were identified by immunoreactivity for chromogranin A and TH. Histochemical studies showed

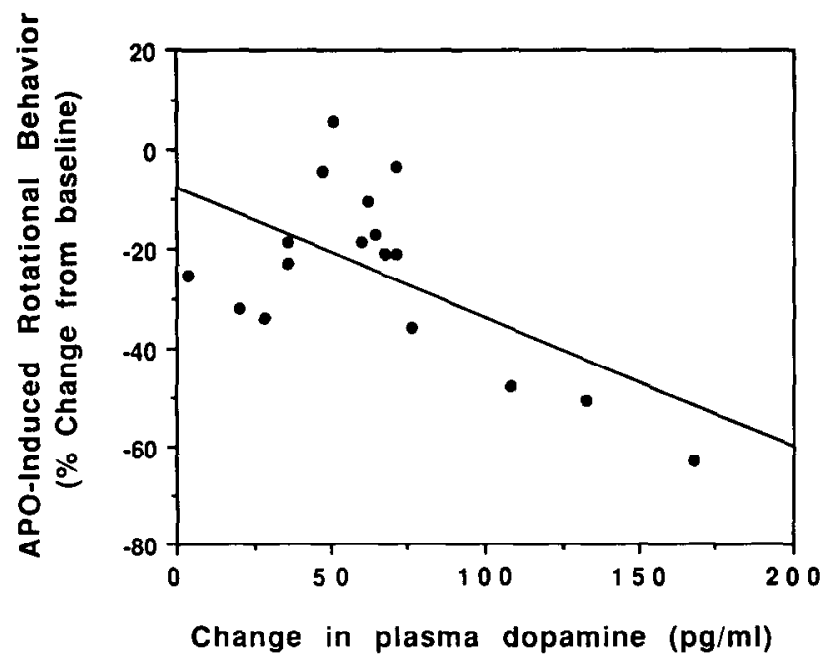

FIG. 6. Correlation between increases in serum dopamine concentrations and the percentage change in apomorphine (APO)-induced rotational behavior in sham-adrenalectomized (ADX) and adrenal medulla grafted groups. In the subgroup of sham-ADX and adrenal medulla grafted animals exhibiting increases in serum dopamine $(n=17)$, the increases in serum dopamine concentrations were inversely correlated with the percentage change in apomorphine-induced rotational behavior (Spearman's rank correlation coefficient, $r_{\mathrm{s}}$ $=-0.603, P<0.01)$. 

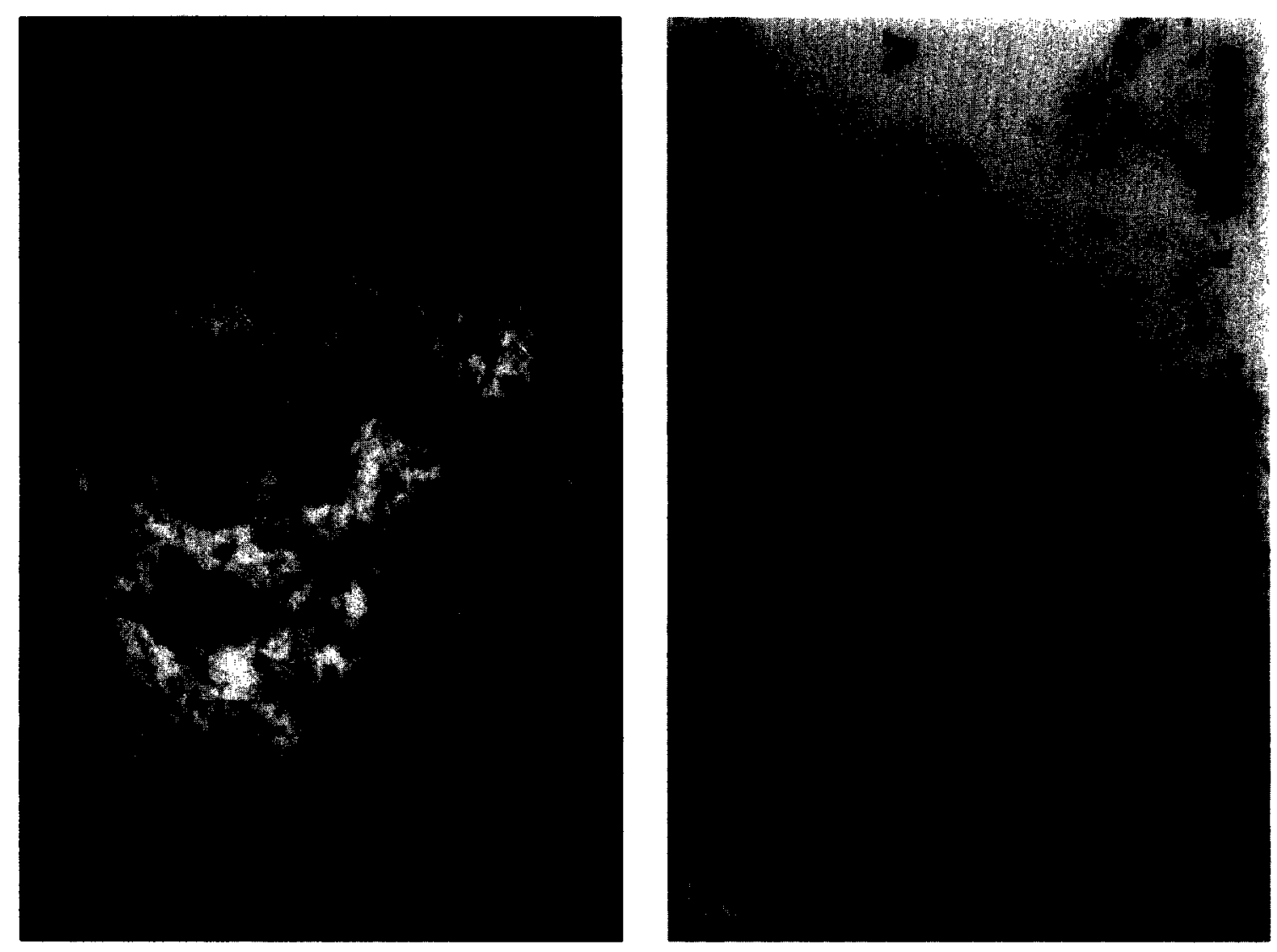

嗐安

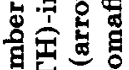
究

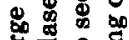

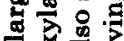

象 क.

(1) क्ष

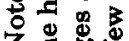

$\mathrm{z}$

i

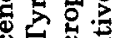

舫

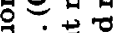

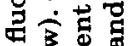

\&

告

현

5 品

$\$$.

of

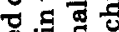

里告

ज के

才。

Uू

응

政

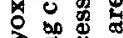

5. 5

동

$\leq$ 롱

灵辟

도의

过

들

Ф.

을 항

돈

능

定定禺

क.

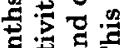

$F$

路 通宁

के

of 뎡.년

들

远的

․․

2

总 国 घू क्ष 萧象 gO

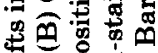
品

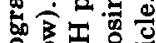
응

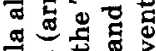
票 웡 a ส 娄 궁 bo

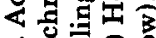
$\therefore$ 的 5

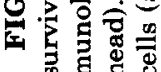



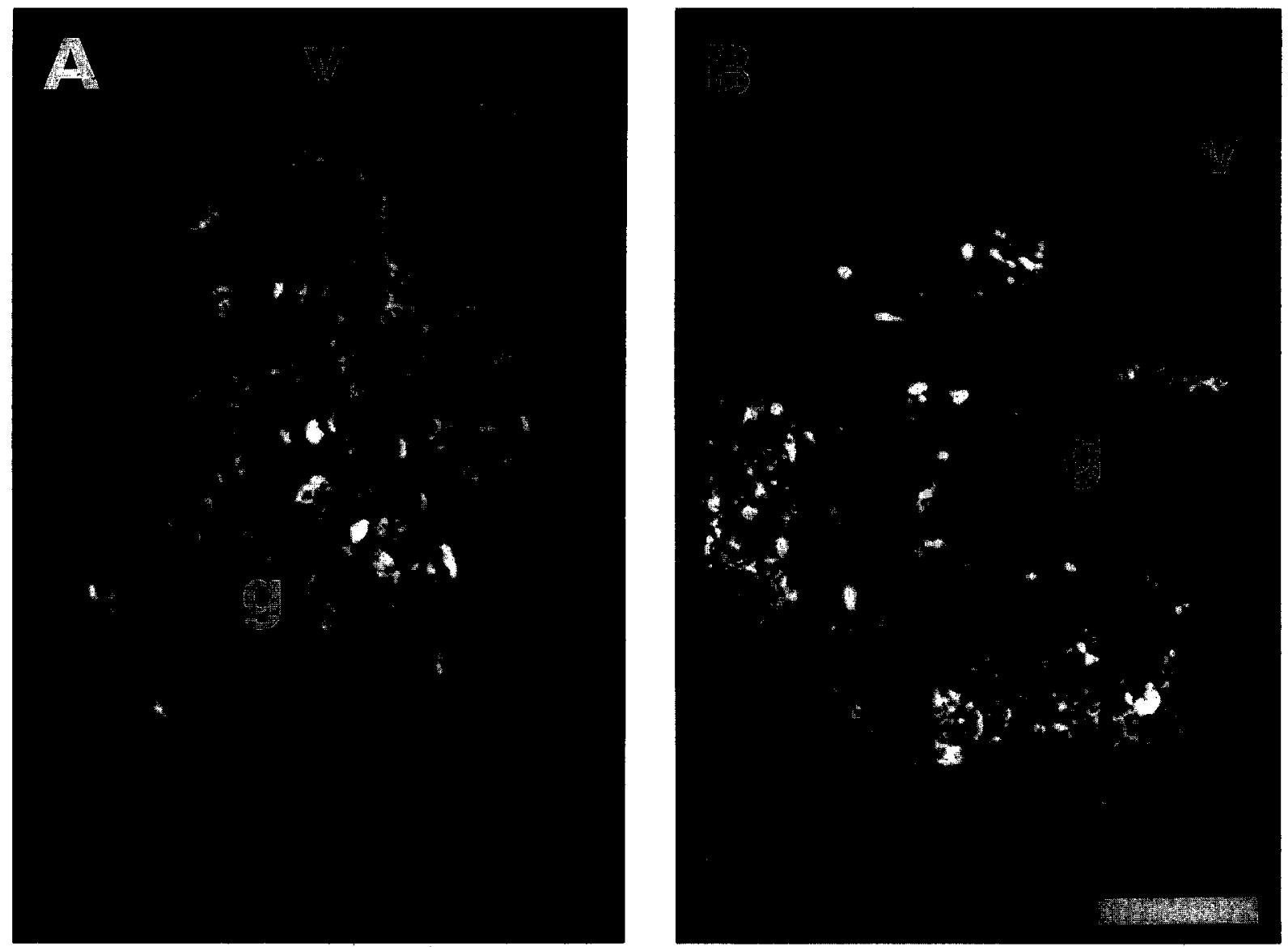

FIG. 8. Tyrosine hydroxylase immunocytochemistry of intraventricular adrenal medulla grafts, 5 months after transplantation (A) and 10 months after transplantation (B). A large group of TH-immunoreactive chromaffin cells can be seen in the graft even 10 months after transplantation. Surviving chromaffin cells were round and did not develop extensive processes. $\mathrm{g}$, Graft; $\mathrm{v}$, ventricle. Bar: $\mathrm{A}=80 \mu \mathrm{m} ; \mathrm{B}=100$ $\mu \mathrm{m}$.

that chromaffin cells were still surviving and expressing TH even 10 months after transplantation. Properties of these cells conform to descriptions of cells transplanted using similar methods given previously $(16,17)$.

\section{Possible Trophic Effects of Adrenal Medulla and Sciatic Nerve Grafts}

Adrenal medulla grafts were reported to promote the reappearance of $\mathrm{TH}$ immunoreactivity in the striatum of MPTP-treated mice (9). This trophic effect also occurs following intracerebral transplantation of nonchromaffin tissue (3). A possible NGF-dependent effect has also been reported, in that intraventricular infusions of NGF were found to decrease rotational behavior when combined with grafts of both chromaffin or nonchromaffin tissues (34). As a possible explanation for this phenomenon, it was suggested that IL-1 produced by macrophages in degenerating tissue causes increased synthesis of NGF by transplanted Schwann cells and fibroblasts (26), and that increased NGF may promote recovery of, or sprouting of, remaining dopamine neurons (9).

In the present study, some sciatic nerve-grafted animals showed decreased apomorphine-induced rotational behavior. Although there was no significant difference between sciatic nerve and sham-grafted animals in the present study, the sciatic nerve group tended to have slightly greater decreases in rotation than the

FIG. 9. Adrenal medulla and sciatic nerve grafts 5 months after transplantation. (A) Adrenal medulla graft processed for in situ hybridization with an alkaline phosphatase-labeled oligonucleotide probe for TH mRNA. Only the graft was stained, and the center of the graft is devoid of cells expressing TH mRNA. (B, C, D) Hematoxylin- and eosin-stained sections illustrating the size of typical adrenal medulla (B) and sciatic nerve grafts (C) (D). Sciatic nerve grafts survived and were generally somewhat larger than the adrenal medulla grafts. g, Graft; $v$, ventricle. Bar: $\mathrm{A}=130 \mu \mathrm{m} ; \mathrm{B}-\mathrm{D}=200 \mu \mathrm{m}$. 

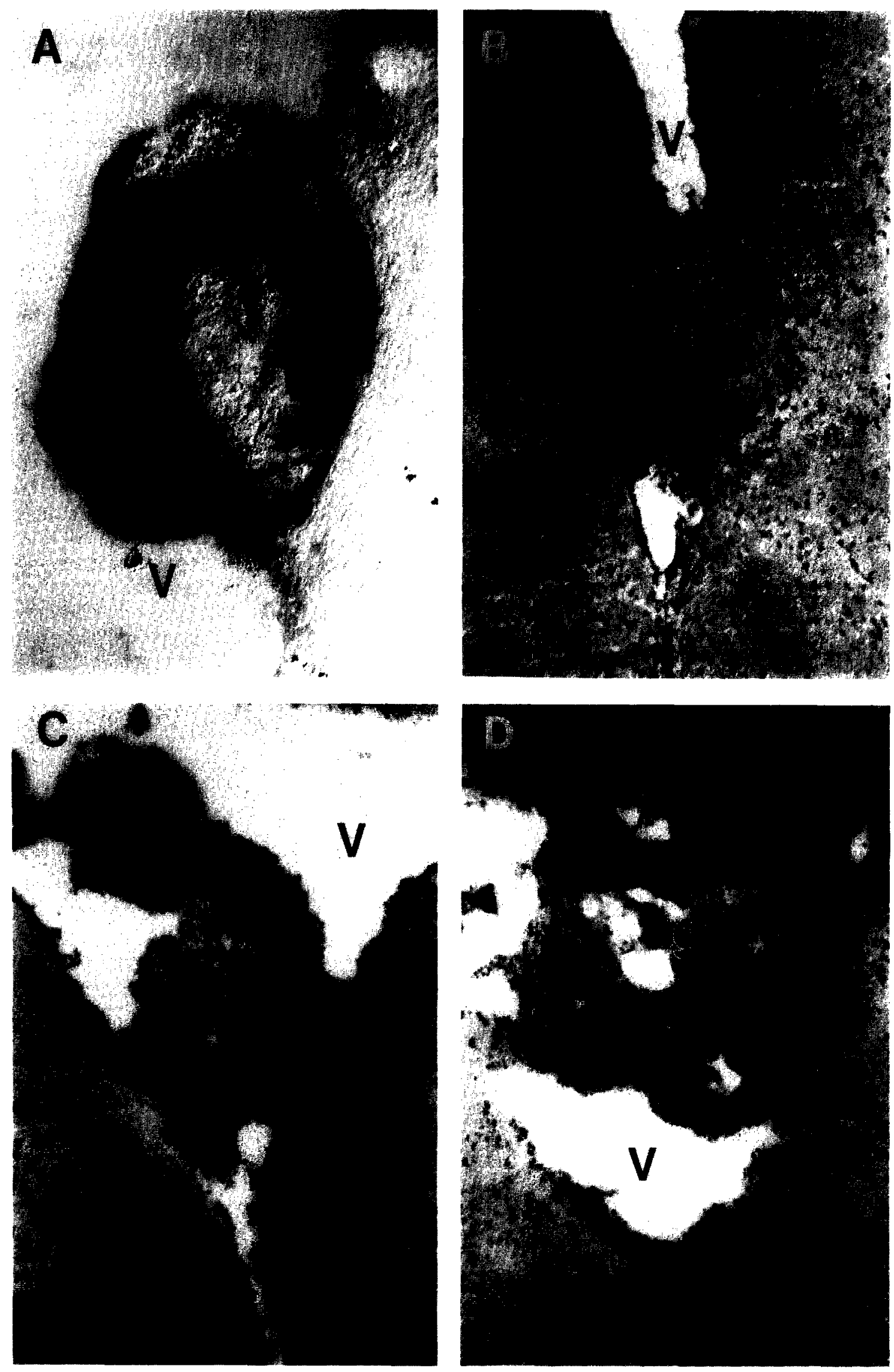
sham-grafted animals. Since the sciatic nerve and sham-graft groups contained fewer animals than the adrenal medulla graft groups, the possibility that sciatic nerve grafts are capable of slightly decreasing rotation cannot be entirely ruled out. Any difference between the sciatic nerve and sham graft groups could be related to trophic effects of the grafts as suggested by in vitro and in vivo studies (12). Sprouting of endogenous TH immunoreactive fibers was not observed in the present study.

\section{Nonspecific Plasma Dopamine Increase in Sham-ADX Animals}

We initially hypothesized that catecholamines secreted into local blood vessels from grafts are transported into the host brain through the circulatory system and then leak into the host brain through areas of increased blood vessel permeability adjacent to grafts (4). In support of this idea, adrenal medulla grafts have been reported to produce local impairment of the blood-brain barrier as revealed by penetration of horseradish peroxidase into the brain $(37,38)$ and penetration of dopamine into the striatum after peripheral administration (13).

In previous studies concerning this hypothesis, changes in dopamine concentrations in peripheral blood were found to be correlated with the behavioral efficacy of intraventricular adrenal medulla grafts, as measured by reductions in apomorphine-induced rotational behavior in rats with intact adrenal glands $(4,6,7)$. In the present study, plasma dopamine increased nonspecifically in each of the sham-ADX groups, irrespective of graft treatment. These increases may have been mediated by the host adrenal medulla, in that increases in plasma dopamine were not seen in ADX animals. It is unclear why the sham-grafting procedure, consisting only of opening a hole in the skull, induced increases in plasma dopamine in animals with intact adrenal medullae. One possibility is the influence on the animals of stress, in the form of handling and receiving injections of apomorphine, amphetamine, and nicotine. Longterm stress and handling could have induced increased catecholamine levels in rats with intact adrenal medullae (24). The ADX rats, in addition to having no adrenal medulla, also did not have adrenal cortex and thus may not have had a normal capacity to respond to chronic stress. For both reasons, systemic catecholamine levels may not have increased in the ADX animals. Another possible contributor to the increases in catecholamine levels might be related to the increased age of the animals after transplantation $(1,23,30)$. Although the causes are unclear, these nonspecific plasma catecholamine increases may be related to the differences in recovery of rotational behavior between sham-ADX and ADX animals.

In the present study, no increases in plasma dopamine were seen in any of the subgroups of ADX animals, including the adrenal medulla grafted group. This suggests that the increase in plasma dopamine following adrenal medulla grafts is derived from the host adrenal gland, not from the grafts. On the other hand, in a previous experiment, an increase in plasma dopamine was also seen in ADX animals (7). This previous experiment included only a small number of ADX animals $(n=9)$. In the present study only 9 of the $24 \mathrm{ADX}$ animals showed increases in plasma dopamine, whereas the other 15 showed decreases or no change. Thus, it is also possible that the increases in plasma dopamine are due to changes in peripheral nervous system function and/ or an adrenal/peripheral nervous system interaction.

\section{Decreases in Apomorphine-Induced Rotation may Reflect a Combination of Nonspecific and Specific Effects of the Adrenal Medulla Grafts}

In the present study, two separate effects were observed. One effect was a decrease in apomorphine-induced rotation after surgery in all groups with intact adrenal glands, as compared to the ADX groups. The second effect was a greater decrease in apomorphine-induced rotation in the animals that received adrenal medulla grafts as compared to the other groups. The adrenalectomy effect was independent of the graft effect and vice versa, as evidenced by the lack of an interaction effect in the analysis of variance. Thus, the decreases in apomorphine-induced rotation seen in intact (i.e., sham-ADX) animals receiving adrenal medulla grafts appear to be due to a combination of two different effects. One is a nonspecific change observed in experimental animals that requires the host adrenal gland and is related to changes in plasma catecholamines. The second effect is a specific effect of adrenal medulla grafts, which exceeds the change observed in animals that receive sham surgery or grafts of other tissues.

The present study does not support the possibility that the specific effect is mediated solely through changes in plasma catecholamines. Although the mechanism for the specific effect of adrenal medulla grafts is not defined, this effect was not produced by sciatic nerve grafts. This specific effect may be mediated by secretion of catecholamines via a paracrine mechanism, by trophic effects specific to adrenal medulla, or by some other process.

Nicotine produces a brisk secretion of catecholamines from adrenal medullae in vivo within 5 min that returns to prestimulation release rates within $30 \mathrm{~min}$ (48). In animals with bovine adrenal medulla grafts in striatum, nicotine sulfate $(0.5 \mathrm{mg} / \mathrm{kg}, \mathrm{SC})$ was reported to evoke contralateral rotation (14). In the present study, some animals turned ipsilaterally, but no animal turned contralaterally, following the injection of nicotine tartrate. $(1.1 \mathrm{mg} / \mathrm{kg}$ of nicotine tartrate is equivalent to $0.5 \mathrm{mg} /$ $\mathrm{kg}$ of nicotine sulfate.) Nicotine induces release of dopa- 
mine from the striatum (49). The injection of nicotine may thus produce a behavioral effect similar to that of amphetamine. A correlation between the number of ipsilateral rotations induced by amphetamine and nicotine was seen. Differences in behavioral reactions between the study by Decombe et al. (14) and the present study may depend on the site of transplantation or the difference in donor tissue species.

\section{Conclusions}

In summary, decreases in rotational behavior were seen specifically in animals that received adrenal medulla grafts as compared to controls. Increased plasma catecholamine concentrations in animals with intact adrenal glands were associated with decreases in rotational behavior, irrespective of graft type. Although the present data do not provide evidence to support a particular mechanism of action, they do suggest that adrenal medulla grafts produce a specific effect which is greater than the effect produced by control procedures (e.g., sciatic nerve grafts). The effects of adrenal medulla grafts on apomorphine-induced rotation observed in intact animals may therefore be due to a combination of two smaller effects: (i) a specific effect of surviving grafts and (ii) a nonspecific effect possibly related to increases in plasma catecholamine concentrations.

\section{ACKNOWLEDGMENTS}

We thank H. Eleanor Cannon-Spoor for technical advice and for editing the manuscript, Eleanor Krauthamer for preparing the histological materials, Ora Dillon-Carter for technical assistance, and the animal care and support staff of the NIMH Neuroscience Center for their invaluable assistance. This work was supported in part by Grant VSPHS (NS22157) to J.B.B. Dr. Becker is supported by a Research Career Development Award (NS01056).

\section{REFERENCES}

1. Avakian, E. V., S. M. Horvath, and R. W. Colburn. 1984. Influence of age and cold stress on plasma catecholamine levels in rats. J. Auton. Nerv. Syst. 10: 127-133.

2. Backlund, E. O., P. O. Granberg, B. Hamberger, E. KNUTSson, A. Martensson, G. Sedvall, A. Seiger, and L. Olson. 1985. Transplantation of adrenal medullary tissue to striatum in parkinsonism. $J$. Neurosurg. 62: 169-173.

3. BANKIEWICZ, K. S., R. J. PlunkeTT, I. J. KopIN, D. M. JACOBOWITZ, W. T. LONDON, AND E. H. OLDFIELD. 1988. Transient behavioral recovery in hemiparkinsonian primates after adrenal medullary autografts. Prog. Brain Res. 78: 507-511.

4. BeCKer, J. B., AND W. J. Freed. 1988. Adrenal medulla grafts enhance functional activity of the striatal dopamine system following substantia nigra lesions. Brain Res. 462: 401-406.

5. BeCKer, J. B., AND W. J. FrEed. 1988. Neurochemical correlates of behavioral changes following intraventricular adrenal medulla grafts: Intraventricular microdialysis in freely moving rats. Prog. Brain Res. 78: 527-533.

6. Becker, J. B., E. J. CURRAN, AND W. J. FreED. 1990. Adrenal medulla graft induced recovery of function in an animal model of Parkinson's disease: Possible mechanisms of action. Can. J. Psychol. 44: 293-310.

7. Becker, J. B., E. J. Curran, W. J. Freed, and M. Poltorak. 1990. Mechanisms of action of adrenal medulla grafts: The possible role of peripheral and central dopamine systems. Prog. Brain Res. 82: 499-507.

8. BJörkiund, A., AND U. STENEvi. 1979. Reconstruction of the nigrostriatal dopamine pathway by intracerebral nigral transplants. Brain Res. 177: 555-560.

9. Bohn, M. C., F. Marciano, L. Cupit, and D. M. Gash. 1987. Adrenal medullary grafts promote recovery of striatal dopaminergic fibers in MPTP treated mice. Science 237: 913-916.

10. Burns, R. S., C. C. Chiveh, S. P. Markey, M. H. EberT, D. M. JACOBOWITZ, AND I. J. KopIN. 1983. A primate model of Parkinsonism: Selective destruction of dopaminergic neurons in the pars compacta of the substantia nigra by n-methyl-4-phenyl1,2,3,6-tetrahydropyridine. Proc. Natl. Acad. Sci. U.S.A. 80: $4546-4550$.

11. Brundin, P., R. E. Strecker, H. Widner, D. J. Clarke, O. G. NiLsson, B. Ăstedt, O. LiNdVALL, AND A. BJöRKLUND. 1988. Human fetal dopamine neurons grafted in a rat model of Parkinson's disease: immunological aspects, spontaneous and drug-induced behaviour, and dopamine release. Exp. Brain Res. 70: 192 208.

12. Collier, T. J., C. D. Sladek, M. J. Gallagher, R. W. Gereau, IV, AND J. E. SPRINGER. 1990. Diffusible factor(s) from adult rat sciatic nerve increases cell number and neurite outgrowth of cultured embryonic ventral mesencephalic tyrosine hydroxylasepositive neurons. J. Neurosci. Res. 27: 394-399.

13. CURRAN, E. J., AND J. B. BECKER. 1991. Changes in blood-brain barrier permeability are associated with behavioral and neurochemical indices of recovery following intraventricular adrenal medulla grafts in an animal model of Parkinson's disease. Exp. Neurol. 114: 184-192.

14. Decombe, R., J. P. Rivot, D. Aunis, N. Abrous, M. PesCHANSKI, AND J. P. HERMAN. 1990. Importance of catecholamine release for the functional action of intrastriatal implants of adrenal medullary cells: Pharmacological analysis and in vivo electrochemistry. Exp. Neurol. 107: 143-153.

15. Fiandaca, M. S., J. H. Kordower, J. T. Hansen, S. S. Jiao, AND D. M. GASH. 1988. Adrenal medullary autografts into the basal ganglia of cebus monkcys: Injury-induced regeneration. Exp. Neurol. 102: 76-91.

16. Freed, W. J., J. M. Morihisa, E. Spoor, B. Hoffer, L. OLson, Å. SEIGER, AND R. J. WYATT. 1981. Transplanted adrenal chromaffin cells in rat brain reduce lesion-induced rotational behavior. Nature 292: 351352.

17. FreED, W. J. 1983. Functional brain tissue transplantation: Reversal of lesion-induced rotation by intraventricular substantia nigra and adrenal medulla grafts, with a note on intracranial retinal grafts. Biol. Psychiatry 18: 1205-1267.

18. Freed, W. J., L. Olson, G. N. Ko, J. M. Morihisa, D. Niehoff, I. STRÖMBERG, M. KUHAR, B. J. HOFFER, AND R. J. WYATT. 1985. Intraventricular substantia nigra and adrenal medulla grafts: Mechanism of action and $\left[{ }^{3} \mathrm{H}\right]$ spiroperidol autoradiography. In Neural Grafting in the Mammalian CNS (A. Björklund and U. Stenevi, Eds.), pp. 471-489. Elsevier, Amsterdam.

19. Freed, W. J., M. PoltoraK, AND J. B. Becker. 1990. Intracerebral adrenal medulla grafts: A review. Exp. Neurol. 110: 139166.

20. GAGE, F. H., AND L. J. FisheR. 1991. Intracerebral grafting: A tool for the neurobiologist. Neuron 6: 1-12.

21. Goetz, C. G., C. W. Olanow, W. C. Koller, R. D. Penn, D. Cahill, R. Morantz, G. Stebbins, C. M. TanNer, H. L. Kla- 
wans, K. M. Shannon, C. L. Comella, T. WitT, C. Cox, M. WAXMAN, AND L. Gauger. 1989. Multicenter study of autologous adrenal medullary transplantation of the corpus striatum in patients with advanced Parkinson's disease. N. Engl. J. Med. 320: $337-341$.

22. HoRNYKIEWICZ, O. 1966. Metabolism of brain dopamine in human parkinsonism: Neurochemical and clinical aspects. In Biochemistry and Pharmacology of the Basal Ganglia (E. Costa, L. J. Cote, and M. D. Yahr, Eds.), pp. 171-181. Raven Press, New York.

23. Kvetnansky, R., E. Jahnova, T. Torda, V. Strbak, and V. BAI.AK. 1978. Changes in adrenal catecholamines and their synthesizing enzymes during ontogenesis and aging in rats. Mech. Ageing Dev. 7: 209-216.

24. Kvetnansky, R., S. Nemeth, M. Vigas, Z. OpRsalova, AND J. JuRCovicova. 1984. Plasma catecholamines in rats during adaptation to intermittent exposure to different stressors. In Stress: The Role of Catecholamines and other neurotransmitters (E. Usdin, R. Kvetnansky, and J. Axelrod, Eds.), pp. 537-562. Gordon and Breach, New York.

25. Langston, J. W., P. Ballard, J. W. Tetrud, and I. Irwin. 1983. Chronic parkinsonism in humans due to a product of mepedrine analogue synthesis. Science 219: 979-980.

26. Lindholm, D., R. Heumann, M. Meyer, and H. Thoenen. 1987. Interleukin-1 regulates synthesis of nerve growth factor in non-neuronal cells of rat sciatic nerve. Nature 330: 658-659.

27. Lindvall, O., P. Brundin, H. Windner, S. ReHNCRona, B. Gustavil, R. Frackowiak, K. L. Leenders, G. Sawle, J. C. ROTHWELL, C. D. MARSDEN, AND A. BJÖRKLUND. 1990. Grafts of fetal dopamine neurons survive and improve motor function in Parkinson's disease. Science 247: 574-577.

28. LoREN, I., A. BJörkLund, O. Lindvald, AND R. H. SCHMIDT. 1982. Improved catecholamine histofluorescence in the developing brain based on the magnesium and aluminium (ALFA) perfusion techniques: Methodology and anatomical observations. Brain Res. Bull. 9: 11-26.

29. Madrazo, I., R. Drucker-Colin, V. Diaz, J. Martinez-Mata, C. TORRES, AND J. J. BECERRIL. 1987. Open microsurgical autograft of adrenal medulla to the right caudate nucleus in two patients with intractable Parkinson's disease. New Engl. J. Med. 316: 831-834.

30. Nekvasil, N. P., AND T. R. KingsLey. 1989. Age-related changes in adrenal catecholamine levels and medullary structure in male Lobund-Wistar rats. Progress in Clinical and Biological Research, Vol. 287, Dietary Restriction and Aging: Symposium on the Effects of Dietary Restriction on Aging and Disease in Germfree and Conventional Lobund-Wistar rats (D. L. Snyder, Ed.), pp. 147-156. Alan R. Liss., New York.

31. Olanow, C. W., W. Koller, C. G. Goetz, G. T. Stebbins, D. W. Cahill, L. L. Gauger, R. Morantz, R. D. Penn, C. M. Tanner, H. L. Klawans, K. M. Shannon, C. L. Comella, and T. WITT. 1990. Autologous transplantation of adrenal medulla in Parkinson's disease: 18-month results. Arch. Neurol. 47: 1286-1289.

32. OTTO, D., AND K. UNSICKER. 1990. Basic FGF reverses chemical and morphological deficits in the nigrostriatal system of MPTP treated mice. J. Neurosci. 10: 1912-1921.

33. Perlow, M. J., W. J. Freed, B. J. Hoffer, Å. Seiger, L. Olson, AND R. J. WYATT. 1979. Brain grafts reduce motor abnormalities produced by destruction of nigrostriatal dopamine system. Science 204: 643-647.

34. Pezzoli, G. S., Fahn, A. Dwork, D. D. Truong, J. G. De Ye-
BENES, V. JACKSON-LewiS, J. HerberT, AND J. L. CADET. 1988. Non-chromaffin tissue plus nerve growth factor reduces experimental parkinsonism in aged rats. Brain Res. 459: 398-403.

35. PoltoraK, M., AND W. J. Freed. 1990. Cell adhesion molecules in adrenal medulla grafts: Enhancement of chromaffin cell L1/ $\mathrm{Ng}$-CAM expression and reorganization of extracellular matrix following transplantation. Exp. Neurol. 110: 73-85.

36. Redmond, D. E., J. R. Sladek, JR., R. H. Roth, T. J. Collier, AND J. D. ELsworTH. 1986. Fetal neuronal grafts in monkeys given methylphenyltetrahydropyridine. Lancet 1: 1125-1127.

37. Rosenstein, J. M., AND M. W. BRIGHTMAN. 1986. Alterations of the blood-brain barrier after transplantation of autonomic ganglia into the mammalian nervous system. J. Comp. Neurol. 250: $339-351$.

38. ROSENSTEIN, J. M. 1987. Adrenal medulla grafts produce bloodbrain barrier dysfunction. Brain Res. 414: 192-196.

39. SCHACHNER, M. 1983. Immunohistochemistry and immunocytochemistry of neural cell types in vitro and in situ. In Immunohistochemistry (A. Cuello, Ed.), pp. 399-429. IBRO Handbook Methods in the Neurosciences Series. Wiley-Interscience, New York.

40. Simonds, G. W., S. Schwartz, E. Krauthamer, and W. J. FREED. 1990. Effects of adrenal medulla grafts in neonatal rat hosts on subsequent bilateral substantia nigra lesions. Restorative Neurol. Neurosci. 1: 315-322.

41. StrömBERg, I., M. HERRERA-MARSchitZ, U. UNGerstedT, T. EBENDAL, AND L. OLSON. 1985. Chronic implants of chromaffin tissue into the dopamine-denervated rat striatum. Effects of NGF on graft survival, fiber growth and rotational behavior. Exp. Brain Res. 60: 335-349.

42. Strömberg, I., P. Almqvist, M. Bygdeman, T. E. Finger, G. Gerhardt, A. C. Granholm, T. J. Mahalik, A. Seiger, L. OLSON, AND B. HOFFER. 1989. Human fetal mesencephalic tissue grafted to dopamine-denervated striatum of athymic rats: Lightand electron-microscopical histochemistry and in vivo chronoamperometric studies. J. Neurosci. 9: 614-624.

43. DE LA TORRE, J. C. 1980. An improved approach to histofluorescence using the SPG method for tissue monoamines. J. Neurosci. Methods 3: 1-5.

44. Tyce, G. M., J. E. Ahlskog, S. W. Carmichael, S. L. CritTon, S. L. SToddard, J. A. van HeERde, T. L. Yaksh, aND P. J. KeLLY. 1989. Catecholamines in CSF, plasma, and tissue after autologous transplantation of adrenal medulla to the brain in patients with Parkinson's disease. J. Lab. Clin. Med. 114: 185192.

45. UNGERSTEDT, U. 1971. Striatal dopamine release after amphetamine or nerve degeneration revealed by rotational behaviour. Acta Physiol. Scand. Suppl. 367: 49-68.

46. UNGERSTEDT, U. 1971. Postsynaptic supersensitivity after 6-hydroxydopamine induced degeneration of the nigro-striatal dopamine system. Acta Physiol. Scand. Suppl. 367: 69-93.

47. Ungerstedt, U. 1974. Functional dynamics of central monoamine pathways. In The Neurosciences: Third Study Program (F. O. Schmitt, and F. G. Worden, Eds.), pp. 979-988. MIT Press, Cambridge, $M A$.

48. WAKADE, A. R., AND T. D. WAKADE. 1983. Contribution of nicotinic and muscarinic receptors in the secretion of catecholamines evoked by endogenous and exogenous acetylcholine. Neurosci. 10: 973-978.

49. Westrall, T. C., H. Grant, and H. Perry. 1983. Release of dopamine and 5-hydroxytryptamine from rat striatal slices following activation of nicotinic-cholinergic receptors. Gen. Pharmacol. 14: 321-325. 